the defunct Black Arrow project. No worthwhile advances can be made in the development of space vehicles, according to the committee, unless there is a comprehensive research and development effort in the programme.

\section{SCIENCE POLICY \\ France and Innovation}

from La Recherche

THE Ministry of Industrial and Scientific Research launched a campaign to promote innovation, in Paris, on November 8, with a colloquium on "Innovation and Progress". About a thousand people took part, representing government, industry, universities and think tanks.

The central issue was naturally that of what can be done by the state and entrepreneurs to stimulate the innovative processes. As so often in meetings of this kind, very few really new ideas emerged. It was nevertheless significant that people from all walks of life gathered at an officially sponsored meeting to agree that France is engaged in serious technological competition. They also agreed that France lags considerably in the world technological race, and the various talks, debates and discussions were dominated by the significance of technical and commercial innovation in the process of total competition among industrialized nations. The immediate issues are how best to transform research into development, the role of small and medium enterprise in this process, and the need to create sources of venture capital to assure profitable innovation.

The three-day meeting was also an opportunity for the Ministry of Industrial and Scientific Research to publicize its own moves earlier this year to spur innovation. These measures are chiefly economic and seek to encourage innovation by way of fiscal relief. One of them eases the added-value tax structure at the point of licensing patents for processing and manufacturing techniques. Another smoothes the way for financial corporations which can invest in innovative enterprises by easing the amortization schedules affecting investment capital. There is yet another scheme to establish a public corporation using state funds to finance innovation.

Another goal of the conference was to provide a shop window for the setting up of a National Foundation for Innovation that will be aimed at invigorating research, disseminating information and organizing conferences on innovation.

Until recently, it was fashionable in France to talk about setting up scientific-industrial complexes, but the difficulties encountered recently by such complexes particularly in the United States, together with a lack of enthu- siasm on the part of both industry and government in France, have taken the steam out of the concept. Both the government and business now realize that it takes more than good public relations to make this dream come true. Innovation has also been halted by gallic apprehension, as $\mathrm{M}$. Duclos of the Société Montabert reminded his audience, that "Qui dit nouveau en France, dit suspect".

Some participants at the colloquium suggested that it takes more than a well organized meeting such as this to clear all the hurdles and avoid the pitfalls to innovation in a country like France. (Asked about the costs involved in organizing the colloquium, a ministry spokesman would only comment, "C'est très délicat.") Is meaningful innovation really possible in a society whose elite elements linger on, whose government-industry-university establishments will not communicate, and whose institutions remain essentially impervious to the seeping in of external influences? If the meeting had any merit at all, it was that of letting the French research and development world ask itself these very questions.

\section{INDUSTRIAL RELATIONS}

\section{Stirring in the Ranks}

IN spite of assurances to the contrary, the United Kingdom Association of Professional Engineers (UKAPE) is forming a Civil Service Division which hopes to be recognized by the Civil Service Department as the negotiating body for government engineers who are, at present, represented by the Institution of Professional Civil Servants (IPCS). This development springs from the complaint of some civil service engineers about IPCS representation. They claim that technicians are filling professional posts and, by their majority over professionals on committees, are denying the engineers an effective voice. As a result Mr Kenneth Peplow, general secretary of UKAPE, approached IPCS last year and suggested an affiliation between the two to give the engineers a stronger voice. When the proposal was rejected, the UKAPE formed its Civil Service Division in spite of the statement by $\mathrm{Mr}$ Peplow during negotiations that his association "would not try to usurp in any way the negotiation arrangements of your association".

$\mathrm{Mr}$ C. Cooper, deputy general secretary of IPCS, said this week that there is no basis for the complaints. He said that the engineers are part of the works group, which includes architects and surveyors, and are represented by a professional staffs committee-which has said that there is no place for UKAPE in the civil service.

Mr E. Pallant, the national organizer of UKAPE's civil service division, said last week that the division was formed as the result of pressure from within the civil service rather than from the association's headquarters. He thinks that once the division is recognized by the Civil Service Department eighty per cent of engineers will join the association. As things stand, only some fifteen out of the 10,000 government engineers are committed to the division, but recruitment is due to start in the next few days. If sufficient numbers support the association it will apply for recognition to the Civil Service Department and, if it is refused, to the Industrial Court for a ballot under the Industrial Relations Act which could force the department-and IPCS - to recognize the division.

Mr Cooper describes this plan as "impossible" and says that if UKAPE thinks it will work "they are living in fairyland" as IPCS already represents engineers effectively and has a membership of 80 per cent among government engineers. $\mathrm{Mr}$ Cooper does not deny that engineers have problems over pay and careers but he hopes to see progress made when the new negotiations begin on January 1 next year-when IPCS, not the division, will be representing the engineers. $\mathrm{Mr}$ Cooper said that there are no doubt a few dissidents but there is no mass movement of engineers to UKAPE. "Their cause will not be advanced by dissipating their efforts," says $\mathrm{Mr}$ Cooper, "and the last thing we want is recruitment wars."

\section{COMPUTERS \\ All Things to All Men}

Although computer companies in Britain have reacted favourably to the Select Committee on Science and Technology's report on prospects for the British computer industry, there have

\section{Royal Society Medals}

THE three Royal Medals of the Royal Society for 1971 have been awarded to Dr G. Herzberg, National Research Council of Canada, for his "distinguished experimental researches in atomic and molecular spectroscopy and its applications in chemistry, physics and astronomy", to Dr M. F Perutz, Medical Research Council Laboratory of Molecular Biology, for "pioneering work on the molecular biology and structure of proteins" and to Dr P. E. Kent, British Petroleum Company Ltd, for "distinguished contributions to oil and gas explorations and the geo$\log y$ of oil and gas fields". 